\title{
The Global Gridded Crop Model Intercomparison: data and modeling protocols for Phase 1 (v1.0)
}

\author{
J. Elliott ${ }^{1}$, C. Müller ${ }^{2}$, D. Deryng ${ }^{3}$, J. Chryssanthacopoulos ${ }^{4}$, K. J. Boote ${ }^{5}$, M. Büchner ${ }^{2}$, I. Foster ${ }^{1}$, M. Glotter ${ }^{6}$, \\ J. Heinke ${ }^{7,2,14}$, T. Iizumi ${ }^{8}$, R. C. Izaurralde ${ }^{9}$, N. D. Mueller ${ }^{10}$, D. K. Ray $^{11}$, C. Rosenzweig $^{12}$, A. C. Ruane ${ }^{12}$, and \\ J. Sheffield ${ }^{13}$ \\ ${ }^{1}$ University of Chicago \& Argonne Natl. Lab Computation Institute, Chicago, Illinois, USA \\ ${ }^{2}$ Potsdam Institute for Climate Impact Research, Potsdam, Germany \\ ${ }^{3}$ Tyndall Centre, University of East Anglia, Norwich, UK \\ ${ }^{4}$ Columbia University Center for Climate Systems Research, New York, New York, USA \\ ${ }^{5}$ University of Florida Department of Agronomy, Gainesville, Florida, USA \\ ${ }^{6}$ University of Chicago Department of Geophysical Science, Chicago, Illinois, USA \\ ${ }^{7}$ International Livestock Research Institute, Nairobi, Kenya \\ ${ }^{8}$ National Institute for Agro-Environmental Sciences, Tsukuba, Ibaraki, Japan \\ ${ }^{9}$ University of Maryland Dept. of Geographical Sciences, College Park, Maryland, USA \\ ${ }^{10}$ Harvard University Center for the Environment, Cambridge, Massachusetts, USA \\ ${ }^{11}$ University of Minnesota Institute for the Environment, Saint Paul, Minnesota, USA \\ ${ }^{12}$ NASA Goddard Institute for Space Studies, New York, New York, USA \\ ${ }^{13}$ Princeton University Dept. Civil \& Environ. Engineering, Princeton, New Jersey, USA \\ ${ }^{14}$ CSIRO (Commonwealth Scientific and Industrial Research Organization), St Lucia QLD 4067, Australia
}

Correspondence to: J. Elliott (jelliott@ci.uchicago.edu) and C. Müller (cmueller@pik-potsdam.de)

Received: 3 June 2014 - Published in Geosci. Model Dev. Discuss.: 15 July 2014

Revised: 19 November 2014 - Accepted: 23 December 2014 - Published: 11 February 2015

\begin{abstract}
We present protocols and input data for Phase 1 of the Global Gridded Crop Model Intercomparison, a project of the Agricultural Model Intercomparison and Improvement Project (AgMIP). The project includes global simulations of yields, phenologies, and many land-surface fluxes using 1215 modeling groups for many crops, climate forcing data sets, and scenarios over the historical period from 1948 to 2012. The primary outcomes of the project include (1) a detailed comparison of the major differences and similarities among global models commonly used for large-scale climate impact assessment, (2) an evaluation of model and ensemble hindcasting skill, (3) quantification of key uncertainties from climate input data, model choice, and other sources, and (4) a multi-model analysis of the agricultural impacts of largescale climate extremes from the historical record.
\end{abstract}

\section{Introduction}

Climate change presents a significant risk for agricultural productivity in many key regions, even under relatively optimistic scenarios for near-term mitigation efforts (Rosenzweig et al., 2014). Consistent global-scale evaluation of crop productivity is essential for assessing the likely impacts of climate change and identifying system vulnerabilities and potential adaptations. Over the last several years, many research groups around the world have developed global gridded crop models (GGCMs) to simulate crop productivity and climate impacts at relatively high spatial resolution over continental and global extents, with a huge diversity of methodologies and assumptions leading to a wide range of results.

In 2012 and 2013, the Agricultural Model Intercomparison and Improvement Project (AgMIP) (Rosenzweig et al., 2013) led a global Fast Track climate impact assessment in coordination with the Inter-Sectoral Impacts Model Intercompari- 
Table 1. Models and groups engaged thus far for GGCMI.

\begin{tabular}{|c|c|c|c|}
\hline Model & Lead institution & Contact(s) & Model type and notes \\
\hline pDSSAT $^{\mathrm{a}, \mathrm{c}, \mathrm{d}}$ & U of Chicago, USA & jelliott@ci.uchicago.edu & Site-based process (Elliott et al., 2014b) (DSSAT 4.5, Jones et al., 2003) \\
\hline EPIC-Boku ${ }^{\mathrm{b}, \mathrm{c}, \mathrm{d}}$ & Boku, Austria & erwin.schmid@boku.ac.at & Site-based process (EPIC v0810) (Balkovič et al., 2013) \\
\hline $\mathrm{GEPIC}^{\mathrm{b}, \mathrm{c}, \mathrm{d}}$ & EAWAG, Switzerland & folberth@iiasa.ac.at & Site-based process (EPIC v0810) (Liu et al., 2007) \\
\hline pAPSIM ${ }^{\text {a,d }}$ & U of Chicago, USA & jelliott@ci.uchicago.edu & $\begin{array}{l}\text { Site-based process (APSIM v7.5) } \\
\text { (Elliott et al., 2014b; Keating et al., 2003) }\end{array}$ \\
\hline EPIC-IIASA ${ }^{\text {b,d }}$ & IIASA, Austria & khabarov@iiasa.ac.at & Site-based process (EPIC v0810) (Balkovič et al., 2013) \\
\hline EPIC-TAMU ${ }^{\mathrm{b}, \mathrm{d}}$ & TAMU and UMD, USA & cizaurra@umd.edu & Site-based process (EPIC v1102) (Izaurralde et al., 2006) \\
\hline CropSyst $^{\mathrm{e}}$ & WSU, USA & stockle@wsu.edu & Site-based process (Stöckle et al., 2003) \\
\hline DAYCENT $^{\mathrm{e}}$ & Colorado State, USA & dennis.ojima@colostate.edu & Site-based process (Stehfest et al., 2007) \\
\hline $\mathrm{LPJmL}^{\mathrm{c}}$ & PIK, Germany & cmueller@pik-potsdam.de & DGVM (Bondeau et al., 2007; Müller and Robertson, 2014) \\
\hline ORCHIDEE & IPSL, France & nathalie.de-noblet@1sce.ipsl.fr & DGVM (de Noblet-Ducoudre et al., 2004) \\
\hline ORCHIDEE-crop & LSCE-IPSL, France & philippe.ciais@1sce.ipsl.fr & DGVM (Valade et al., 2014) \\
\hline LPJ-GUESS ${ }^{\mathrm{c}}$ & KIT, Germany & almut.arneth@kit.edu & DGVM (Lindeskog et al., 2013; Smith et al., 2001) \\
\hline JULES-crop ${ }^{\mathrm{e}}$ & Met Office, UK & pete.falloon@metoffice.gov.uk & DGVM (Van den Hoof et al., 2011) \\
\hline CLM-Crop & LBNL, USA & adjones@lbl.gov & DGVM (Levis et al., 2012; Drewniak et al., 2013) \\
\hline PEGASUS ${ }^{\mathrm{c}}$ & Tyndall, UEA, UK & d.deryng@uea.ac.uk & Empirical/process (Deryng et al., 2011, 2014) \\
\hline GLAM $^{\mathrm{e}}$ & SEE, Leeds, UK & a.j.challinor@leeds.ac.uk & Empirical/process (Challinor et al., 2004) \\
\hline CGMS & WUR, NL & allard.dewit@wur.nl & $\begin{array}{l}\text { Empirical/process (WOFOST) (van Diepen et al., 1989; Supit et al., } \\
\text { 1994) }\end{array}$ \\
\hline PRYSBI- 2 & NIAES, Japan & iizumit@affrc.go.jp & Empirical/process (Okada et al., 2011) \\
\hline MCWLA $^{\mathrm{e}}$ & IGSNRR, China & taofl@igsnrr.ac.cn & Empirical/process (Tao and Zhang, 2012) \\
\hline ISAM & UIUC, USA & jain1@illinois.edu & DGVM (Song et al., 2013) \\
\hline DLEM-Ag & Auburn U, USA & renwei@auburn.edu & DGVM (Gueneau et al., 2012) \\
\hline
\end{tabular}

son Project (ISI-MIP) (Warszawski et al., 2014) that brought together a group of GGCMs to simulate future crop productivity under various climate change and farm management scenarios (Elliott et al., 2014a; Rosenzweig et al., 2014; Piontek et al., 2014; Nelson et al., 2014). Increased application of crop growth models for global-scale analyses and the wide variation in model assumptions and projected outputs found in the Fast-Track assessment inspired the launch of the AgMIP GRIDded crop modeling initiative (Ag-GRID) and the Global Gridded Crop Model Intercomparison (GGCMI). We define here the simulation protocol for the first phase of the GGCMI, which is designed to, among other things, enable comprehensive evaluation of model and ensemble skill - with respect to yield levels, variability, and large-scale extreme events - based on comparisons of simulations and observations over the last several decades.

The GGCMI Phase 1 simulation protocol includes participants that run a number of gridded crop models (listed with contacts and short descriptions in Table 1), driven with consistent inputs based on multiple weather data products (to evaluate uncertainties from weather data) and harmonized management practice data (planting date, growing season length, and fertilizer inputs). The results of these different simulation runs will then be compared to three distinct reference data sets derived from census and remote sensing data sources (Ray et al., 2013; Iizumi et al., 2013; FAOSTAT data, 2013). GGCMI is a protocol-based simulation experiment for gridded crop models and is open to the participation of any model group that simulates crop productivity at the global scale, including models developed for field-scale application, biogeochemical dynamic global vegetation and land-surface scheme models, empirical-process-based hybrid models, and statistical models.

In the modeling protocol presented here, we describe the simulation experiments and priorities, central inputs provided to modelers, required outputs to be provided by modeling groups, and data format conventions. GGCMI protocols are designed to overlap as much as possible with and contribute to the refinement of the modeling protocols of the next phase of ISI-MIP (ISI-MIP2). Modelers participating in GGCMI can directly participate in ISI-MIP2 if they so desire.

\section{Simulation experiments, models, and objectives}

The primary goals of Phase 1 of the GGCMI are

1. intercomparison of models with and without harmonized inputs and assumptions, and with and without explicit nitrogen stress;

2. evaluation of model and ensemble skill over the historical period;

3. detailed characterization of important uncertainties (weather data, management systems, evapotranspiration 
Table 2. Priority 1 and 2 crops in Phase 1, along with the number of models expected to contribute results for each crop.

\begin{tabular}{|c|c|c|c|c|}
\hline Priority & Crops & Labels & $\begin{array}{l}\text { No. of } \\
\text { models }\end{array}$ & Notes \\
\hline 1 & Wheat, maize, soy, rice & whe, mai, soy, ric & $15-20$ & Required for all objectives \\
\hline 2 & $\begin{array}{l}\text { All others: Managed grass*, sugarcane, } \\
\text { sorghum, millet, rapeseed, sugar beets, bar- } \\
\text { ley, cassava, field peas, sunflower, ground- } \\
\text { nuts, dry bean, cotton, potatoes }\end{array}$ & $\begin{array}{l}\text { mgr, sug, sor, mil, } \\
\text { rap, sgb, bar, cas, } \\
\text { pea, sun, nut, ben, } \\
\text { cot, pot }\end{array}$ & $\begin{array}{l}\text { Based on } \\
\text { availability } \\
(>2)\end{array}$ & $\begin{array}{l}\text { Priority } 2 \text { crops will be consid- } \\
\text { ered case-by-case (require at } \\
\text { least three model submissions) }\end{array}$ \\
\hline
\end{tabular}

* We consider only managed grassland productivity, not unmanaged pasture.

methods, and output processing techniques) in historical crop yield analysis and the implication of these for future climate impact assessment; and

4. multi-model, multi-forcing analysis of the agricultural impacts of large-scale extremes (primarily drought and heat events) in the historical record.

Groups are asked to simulate agricultural productivity for various crops under purely rain-fed as well as fully irrigated conditions for different driving input data sets on weather and management. To avoid overtaxing of modeling groups, we define simulation priorities to facilitate central analyses with an as broad as possible group of GGCMs as well as additional analyses of more specific questions (the performance of crop models for crops beyond wheat, maize, rice, soy; the influence of weather data uncertainty on model performance; and the impact of different evapotranspiration methodologies on model response and model skill in different regions and agro-climatic zones).

\subsection{Crops and management systems to simulate}

We define a two-tiered priority structure that takes into account both the crops that are most important for questions of (primarily global) food security and economics, and the crops that are most commonly simulated in available models. The three main cereal crops (maize, wheat, and rice) alone account for about $43 \%$ of total food energy intake (FAOSTAT data, 2013). Along with soybeans, which are the largest single source of oilseeds globally and an essential source of protein and animal feed, these crops have been the focus of most crop yield and climate impact modeling work, and are generally simulated by all the models participating in GGCMI. Thus, we define them as our Priority 1 crops, representing the minimum set for our analyses (Table 2). Many other crops are important staple food, feed, or energy crops in economically or climate-sensitive regions, and most contributing models within GGCMI do simulate one or more of these secondary (or Priority 2) crops. In order to consider as many crops as possible, we ask modelers to supply data on all crops that they can simulate, and consider any crop simulated by at least three models as valid for a multi-model intercomparison analysis. The participating models cover a broad range of annual crops as well as managed grassland, but provide no modeling capacities for perennial crops (Table 2).

We define three distinct types of model configurations (Table 3 ) for the simulations in Phase 1. First, each group is to develop their own "default" configuration based on the management and technology assumptions and inputs they typically use for simulations in the historical period. Each group must also prepare a "harmonized" configuration using input data, parameters, and definitions provided by the GGCMI coordinators. Finally, each model that considers nitrogen (whether with explicit fertilizers or an empirical calibration) is also to be run in a configuration without nitrogen stress, "harmnon", to allow for direct comparison with models that do not explicitly consider the nitrogen cycle. We define the "hamrnon_firr", which has zero (or near-zero) stress from both nitrogen and water, as "potential yield" for the purpose of defining yield gaps and related analyses.

All modelers are asked to simulate all crops across the globe, irrespective of current cropping areas for purely rainfed as well as irrigated conditions. This approach allows for addressing uncertainties in assumed distributions of cropland in post-processing analysis. The minimum spatial extent of historical simulations is current agricultural land, and we require that all crops be simulated on all agricultural lands, rather than just on the land where they are currently grown.

We assume that irrigated systems are not limited by freshwater availability and have no water losses during conveyance and application. While the latter assumption has no implications for crop growth, it helps to make reported irrigation water quantities comparable across models.

Table 4 summarizes the outputs requested from GGCMI simulations. We require that all models provide two central outputs, dry matter equivalent crop yield and (for irrigated scenarios) total irrigation water requirements. Due to the unique characteristics of different models, few other output variables are available to be contributed by all groups. Rather than limit the project only to those variables that are universally produced (crop yields and applied irrigation water), we list in Table 4 as many additional optional outputs as possible. These optional outputs include, for example, above- 
Table 3. General simulation configurations for Phase 1.

\begin{tabular}{lll}
\hline Config & Long name & Description \\
\hline $\begin{array}{l}\text { Default } \\
\text { fullharm }\end{array}$ & Default configuration & Simulations using default "best guess" choices for all inputs \\
harmnon & Harmonized with no nitrogen & Simulations using harmonized inputs and assumptions \\
\hline
\end{tabular}

Table 4. Output variables to be collected during GGCMI Phase 1. The first two variables are to be provided by every model; other variables are to be provided as possible by each model

\begin{tabular}{|c|c|c|}
\hline Variable & Variable name* & Units (and notes) \\
\hline \multicolumn{3}{|l|}{ Mandatory variables to be provided for all simulations } \\
\hline Crop yields & yield_<crop $>$ & tha $^{-1} \mathrm{yr}^{-1}$ (dry matter $)$ \\
\hline Applied irrigation water & pirrww_<crop $>$ & $\begin{array}{l}\mathrm{mm} \mathrm{yr}^{-1} \text { (firr only, assume loss-free con- } \\
\text { veyance/application) }\end{array}$ \\
\hline \multicolumn{3}{|c|}{ Additional variables below are to be provided as possible by each model } \\
\hline Total above-ground biomass yield & biom_<crop $>$ & $\mathrm{tha}^{-1} \mathrm{yr}^{-1}$ \\
\hline Actual growing season evapotranspiration & aet_<crop $>$ & $\mathrm{mm} \mathrm{yr}^{-1}$ (season only) \\
\hline Actual planting date & plant-day_<crop $>$ & day of year \\
\hline Days from planting to anthesis & anth-day_<crop $>$ & days from planting \\
\hline Days from planting to maturity & maty-day_<crop $>$ & days from planting \\
\hline Nitrogen application rate & initr_<crop $>$ & $\mathrm{kg} \mathrm{ha}^{-1} \mathrm{yr}^{-1}$ \\
\hline Nitrogen leached & leach_<crop $>$ & $\mathrm{kg} \mathrm{ha}^{-1} \mathrm{yr}^{-1}$ \\
\hline Nitrous oxide emissions & $\operatorname{sn} 2 o_{-}<$crop $>$ & $\mathrm{kg} \mathrm{N}_{2} \mathrm{O}-\mathrm{Nha}^{-1}$ \\
\hline Accumulated precipitation, plant to harvest & gsprcp_<crop $>$ & $\mathrm{mm} \mathrm{ha}^{-1} \mathrm{yr}^{-1}$ (season only) \\
\hline Growing season incoming solar & gsrsds_<crop $>$ & $\mathrm{W} \mathrm{m}^{-2} \mathrm{yr}^{-1}$ (season only) \\
\hline Sum of daily mean temperature, planting to harvest & sumt_<crop $>$ & ${ }^{\circ} \mathrm{C}$ days $\mathrm{yr}^{-1}$ (season only) \\
\hline
\end{tabular}

* $<$ crop $>$ refers to the three-letter variable codes (whe, mai, ric, etc.) from Table 2.

ground biomass, accumulated water applied and transpired, accumulated nitrogen applied and lost through leaching, key phenological dates, and growing season climate characteristics. This approach will facilitate better analyses and interpretation of results and will allow GGCMI participants to further leverage the archives for scientific deliverables and overall project impacts.

We ask that modelers archive model versions used for the simulations and all primary outputs generated, in order to allow for reproducibility and facilitate extraction of additional or more detailed (e.g., higher temporal resolution) data that may be found to be necessary for analyses not yet planned.

As far as possible for the models, all modelers should supply yield and irrigation water amounts for at least the four main crops: wheat, maize, rice and soy (Table 2). Simulations should be conducted for default and harmonized management assumptions as well as for different weather data sets. If modeling capacities are constrained, modelers should supply at least the four Priority 1 crops (Table 2) and selected weather-management combinations to allow for a comprehensive model intercomparison across a limited set of scenarios and for analyses of input and assumption uncertainties with those models that contributed (Table 5). Priority 1 denotes the minimum simulations required for participation unless model capacities do not allow for covering the full spectrum of Priority 1 simulations (e.g., because not all crops are implemented, or because a model requires special weather data inputs).

Priority 2 includes two distinct simulation tracks designed around specific science objectives and expected publications. Simulations in the "climate track" (Priority 2.1) are designed to evaluate differences among the forcing products through an agro-climatic lens, enabling assessment of the relative importance of different reanalysis products, bias-correction techniques, and target data sets used for bias-correction. The "crop track" (Priority 2.2) will allow us to expand our analysis to crops that have not been studied as thoroughly as the primary four food crops or that are only important regionally or in non-food contexts (such as energy crops). This expanded set is expected to include managed grass, sugarcane, sorghum, millet, rapeseed, sugar beet, and cassava. 
Table 5. Simulation priorities for Phase 1. For climate product descriptions see Table 9.

\begin{tabular}{|c|c|c|c|c|}
\hline Priority & Crops & Climate product & Scenarios & Goal \\
\hline Priority 1 & $\mathrm{P} 1$ & $\begin{array}{l}\text { WFDEI.GPCC, } \\
\text { AgMERRA }\end{array}$ & $\begin{array}{l}\text { Default, fullharm, } \\
\text { harmnon }\end{array}$ & $\begin{array}{l}\text { Establish key minimal yield estimates and compar- } \\
\text { isons }\end{array}$ \\
\hline Priority 2 & $\mathrm{P} 1$ & $\begin{array}{l}\text { WATCH.GPCC, PGF, } \\
\text { GRASP, AgCFSR }\end{array}$ & fullharm & $\begin{array}{l}\text { Extend range of years and characterize uncertainty } \\
\text { due to multiple forcing products }\end{array}$ \\
\hline $\begin{array}{l}2.1 \text { Climate } \\
\text { track }\end{array}$ & $\mathrm{P} 1$ & $\begin{array}{l}\text { WFDEI.CRU, } \\
\text { ERA-I and CFSR }\end{array}$ & fullharm & $\begin{array}{l}\text { Evaluate the effects of different drivers (pure reanal- } \\
\text { ysis, GPCC vs. CRU target for bias-correction, etc.) }\end{array}$ \\
\hline $\begin{array}{l}\text { 2.2 Crop } \\
\text { Track }\end{array}$ & $\mathrm{P} 2$ & $\begin{array}{l}\text { WFDEI.GPCC, } \\
\text { AgMERRA }\end{array}$ & fullharm & $\begin{array}{l}\text { Evaluate other crops that have a sufficient number of } \\
\text { models and interest }\end{array}$ \\
\hline
\end{tabular}

\subsection{Conventions for simulation outputs}

In order to facilitate analysis, portability, and processing of outputs, results will be collected in compressed, selfdescribing NetCDF v4 files with consistent and relatively simple data, metadata, and file-naming conventions described below.

\subsubsection{File names}

Each file must contain a single output variable and be named according to the following convention (see definitions in Table 6):

[model]_[climate]_[clim.scenario]_[sim.scenario $]$ [variable]_[crop]_[timestep]_[start-year]_[end-year].nc4

For example, pdssat_watch_hist_default_noirr_yield_mai_ annual_1958_2001.nc4

\subsubsection{Geographical extent}

Data must be submitted for the ranges 89.75 to $-89.75^{\circ}$ latitude, and -179.75 to $179.75^{\circ}$ longitude. Thus, each file will contain 360 rows and 720 columns for a total of 259200 grid cells. All ocean grid cells must be filled with the fill value (Table 7). Modelers need not simulate Greenland, the Arctic, or Antarctica but must submit output completely filled for the entire range from latitude 89.75 to -89.75 . Output data must be reported row-wise starting at 89.75 and -179.75 , and ending at -89.75 and 179.75 . As is standard in NetCDF files, latitude, longitude, and time must be included as variables in each file explicitly defining their extent.

\subsubsection{Date reporting convention}

The analysis of inter-seasonal variability of crop yields is complicated by reporting conventions involving the assignment of reported production to calendar years. This issue is especially problematic in the Southern Hemisphere, where harvest sometimes occurs in a window around 31 December so that assignment to calendar years based on the harvest date gives double harvests (e.g., one in early January and the next in late December of the same calendar year) in some years and no harvest in others. The data reporting convention for GGCMI thus is not calendar year but growing season based. That is, results are to be reported as a sequence of growing seasons, irrespective of whether that growing season actually spans 2 calendar years or if harvests occur just before or just after 31 December. Cumulative growing season variables as, e.g., actual evapotranspiration or precipitation are to be accumulated over the growing season, again irrespective of any calendar year definitions, and are to be reported in the same sequence as the harvest events (yield, above-ground biomass). The unit of the time dimension of the NetCDF v4 output file is thus "growing seasons since YYYY-01-01 00:00:00" (Table 7). The first season in the file (with value time $=1$ ) is then the first complete growing season of the time period provided by the input data without any assumed spin-up data, which equates to the growing season with the first planting after this date. This convention roughly corresponds to an annual reporting scheme but allows for a better separation and analysis of outputs. The artificial separation of harvest seasons into 2 different calendar years may, however, also be present in observational data and may complicate evaluation of model skills in these regions anyway.

\section{Central input data}

In order to ensure comparability of simulation results across models and to investigate the importance of uncertainties with respect to weather and management data, we supply central input data to all participating modelers. The GGCMI Phase 1 protocols include a set of assumptions, definitions, and input data products that will be used to harmonize participating models as closely as possible in the fullharm and harmnon configurations (Table 8). During project pre-planning we established data sharing arrangements with leading agricultural data groups that will contribute global high-resolution crop-specific data on key management inputs covering sowing dates, growing season length, fertilizer application rates (including nitrogen, phosphorus, and potassium), manure use, and historical atmospheric $\mathrm{CO}_{2}$ concentration. We will also harmonize a set of definitions and parameter choices among models, ensuring that output data 
Table 6. Filename conventions for standardized model outputs.

\begin{tabular}{ll}
\hline Filename tag [] & Values \\
\hline [model] & pdssat, epic-iiasa, lpjml, etc. (see Table 1) \\
[climate] & watch, wfdei.gpcc, wfdei.cru, grasp, agmerra, agcfsr, Princeton (see Table 9) \\
[clim.scenario] & Hist \\
[sim.scenario] & default_firr, fullharm_noirr, etc. (simulation configuration, see Table 3 and irriga- \\
& tion setting (firr or noirr)) \\
[variable] & yield, pirrww, plant-day, anth-day, etc. (see Table 4) \\
[crop] & mai, soy, whe, ric, mil, sor, etc. (see Table 2) \\
[timestep] & annual \\
[start-year]_[end-year] & 1958_2001, 1980_2009, 1980_2010, etc. (see Table 9) \\
\hline
\end{tabular}

Table 7. NetCDF file dimension, variable, and attribute info.

\begin{tabular}{lllll}
\hline Dimension/variable & Fill value & No.type & Units & Range \\
\hline Longitude & NA & double & degrees east & $-179.75 \ldots 179.75$ \\
Latitude & NA & double & degrees north & $89.75 \ldots-89.75$ \\
Time & NA & double & "growing seasons since YYYY-01-01 & $1 \ldots T(T$ varies, see Table 9). \\
& & & $00: 00: 00 "$ & \\
& & & (YYYY varies, see Table 9) & varies \\
[variable]_[crop] & $1 . e+20 f$ & float & varies (see Tables 2 and 4). & \\
\hline
\end{tabular}

are directly comparable to the greatest extent possible. All GGCMI input data described here can be accessed at https: //rdcep.org/ggcmi/data.

\subsection{Weather data inputs}

In total we will use six historical retrospective-analysisbased forcing data sets (bias-corrected at monthly timescales against observational products such as CRU and GPCC) and two raw (non-bias-corrected) reanalysis products (Table 9). Within the cropping areas of the major crops, these weather products display some uncertainty with respect to mean and variability of weather variables such as temperature (Fig. 1) and precipitation (Fig. 2). We do not strictly harmonize spinup procedures for those models that require it; however, we provide the Princeton global forcing data set for years after 1948, and a decade of generic pre-industrial weather that can be used for all preceding years. We also consider two versions of WFDEI, with biases corrected separately using either the GPCC or CRU data as targets, for a total of nine distinct data products and about 350 years of daily data. In total, this collection provides one or more weather data inputs for every year from 1948 to 2012. All products cover the 30-year period from 1980 to 2009 (which will serve as our primary analysis period) except WATCH (1958-2001) and Princeton (1948-2008). Each data set is provided at daily resolution and one product (WFDEI) is additionally provided at 3-hourly resolution for those models that require sub-daily data.
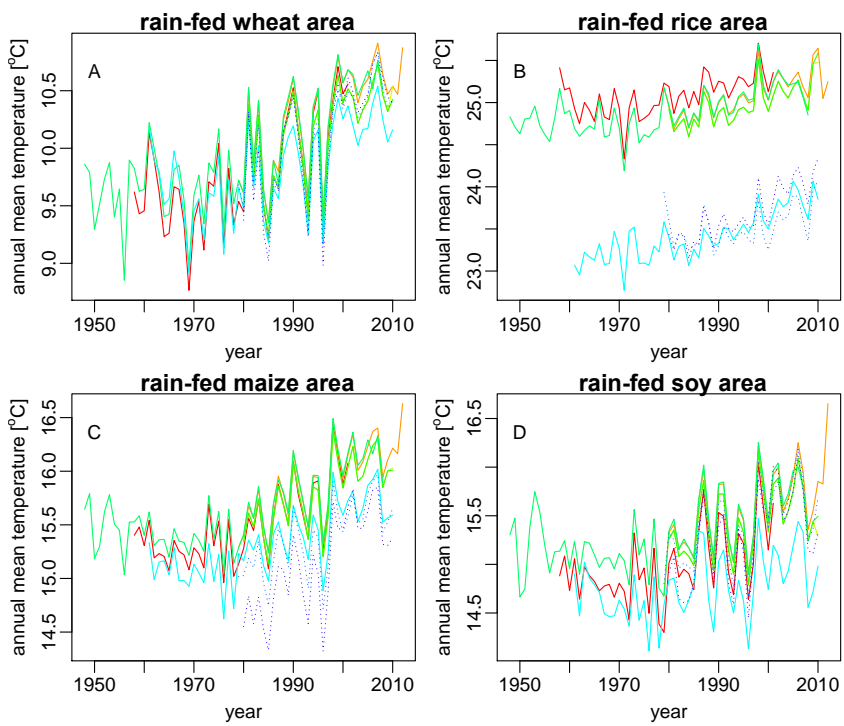

\begin{tabular}{|lll|}
\hline WATCH & AgMERRA & GRASP \\
WFDEI & AgCFSR & ERAI \\
& Princeton & CF..... \\
& & CFSR \\
\hline
\end{tabular}

Figure 1. Area-weighted mean of annual temperatures $\left[{ }^{\circ} \mathrm{C}\right]$ for cropping areas for rain-fed wheat (a), rice (b), maize (c), and soy (d).

Different GGCMs can require different weather variables, which are supplied by the different forcing data sets. Models that require weather variables not included in some data products (e.g., long-wave downward radiation, Table 10) 
Table 8. Harmonized input variable sources for fullharm and harmnon configurations in Phase 1.

\begin{tabular}{|c|c|c|c|}
\hline Variable & Source & Units & Notes \\
\hline Planting window & $\begin{array}{l}\text { Sacks et al. (2010), Port- } \\
\text { mann et al. }(2008,2010) \text { and } \\
\text { environment-based extrapola- } \\
\text { tions }\end{array}$ & $\begin{array}{l}\text { Julian days } \\
(\text { Jan } 1=1, \ldots)\end{array}$ & $\begin{array}{l}\text { Crop calendar data (planting and maturity) for pri- } \\
\text { mary seasons }\end{array}$ \\
\hline Approximate maturity & $\begin{array}{l}\text { Sacks et al. (2010), Port- } \\
\text { mann et al. (2008, 2010) and } \\
\text { environment-based extrapola- } \\
\text { tions }\end{array}$ & $\begin{array}{l}\text { Days/GDD from } \\
\text { sowing }\end{array}$ & $\begin{array}{l}\text { Growing season length provided in number of } \\
\text { days }\end{array}$ \\
\hline Fertilizers and manure & $\begin{array}{l}\text { Mueller et al. (2012), Potter et } \\
\text { al. (2010), Foley et al. (2011) }\end{array}$ & $\mathrm{kg} \mathrm{ha}^{-1} \mathrm{yr}^{-1}$ & $\begin{array}{l}\text { Average nitrogen, phosphorus, and potassium ap- } \\
\text { plication rates in each grid cell }\end{array}$ \\
\hline Historical $\left[\mathrm{CO}_{2}\right]$ & $\begin{array}{l}\text { Mauna Loa/RCP } \\
\text { historical }\end{array}$ & ppm & $\begin{array}{l}\text { Annual and monthly }\left[\mathrm{CO}_{2}\right] \text { values from } 1900 \text { to } \\
2013 \text {. }\end{array}$ \\
\hline Definition of time & Protocol choice & $\begin{array}{l}\text { "growing seasons } \\
\text { since YYYY-01- } \\
01 "\end{array}$ & $\begin{array}{l}\text { YYYY is just the first year in the file. For a run } \\
\text { 1958-2001, YYYY }=1958 \text {. Values of time are in- } \\
\text { dependent of how growing season is assigned to } \\
\text { calendar year. }\end{array}$ \\
\hline Season definition & Protocol choice & Definition & $\begin{array}{l}\text { AET and PirrWW defined as accumulated over the } \\
\text { growing season, not over the calendar year }\end{array}$ \\
\hline Automatic irrigation & $\begin{array}{l}\text { Guidance for parameter } \\
\text { choices }\end{array}$ & Definition & $\begin{array}{l}\text { Management depth }=40 \mathrm{~cm} / \text { Efficiency }=100 \% \\
\text { Lower event trigger threshold }=90 \% \\
\text { Max single AND annual volume }=\text { Unlimited }\end{array}$ \\
\hline
\end{tabular}

should use the equivalent variable from another data set. As weather variables are bias-corrected individually and there is consequently no consistency between the individual variables within one data set, and as all data refer to the historic period, we assume that the errors introduced by this approach are small.

\subsection{Harmonized growing season definitions}

We supply harmonized growing season data (planting and maturity dates) for all Priority 1 crops (wheat, maize, rice, soybeans, see Table 2) plus data for the Priority 2 crops barley, cassava, groundnuts, millet, potatoes, pulses (dry bean, field peas), rapeseed, rye, sorghum, sugar beets, sugarcane, and sunflower. Of the Priority 2 crops, we lack information for cotton, while managed grassland is assumed to grow all year round. We compile growing season data from two existing global crop calendars, MIRCA2000 ${ }^{1}$ (Portmann et al., 2010) and $\mathrm{SAGE}^{2}$ (Sacks et al., 2010), supplementing those data with a rule-based approach as implemented in $\mathrm{LPJmL}^{3}$ (Waha et al., 2012) to provide as much coverage of the global land surface as possible.

\footnotetext{
${ }^{1}$ Available for download at ftp://ftp.rz.uni-frankfurt.de/ pub/uni-frankfurt/physische_geographie/hydrologie/public/ data/MIRCA2000/growing_periods_listed/CELL_SPECIFIC_ CROPPING_CALENDARS_30MN.TXT.gz

${ }^{2}$ Available for download at http://www.sage.wisc.edu/ download/sacks/netCDF0.5degree.html

${ }^{3}$ Available for download at the ISI-MIP Fast Track archive http: //esg.pik-potsdam.de
}

\subsubsection{Methodology}

We use data from two global cropping calendars, MIRCA2000 (Portmann et al., 2010) and SAGE (Sacks et al., 2010), for current cropping regions (or administrative units with cropping activity). To fill areas not covered by MIRCA2000 and SAGE, we use the planting and harvest dates as computed by LPJmL (Waha et al., 2012) as implemented for the ISI-MIP Fast Track (Müller and Robertson, 2014; Rosenzweig et al., 2014). Table 11 shows the availability of crops in the crop calendar data sets and the crops used from LPJmL.

MIRCA2000 data supply up to five growing periods per pixel, each with a specific area. For each pixel, we choose the growing period with the largest area. SAGE data supplies median planting and harvest dates as well as beginning and end of planting/harvest. We use the median dates. Because MIRCA2000 has monthly resolution only, assuming the first of the month for planting dates and the last of the month for harvest dates, we use SAGE data with daily resolution where available, and MIRCA2000 data only in regions where no SAGE data are available. We ignore MIRCA2000 data if growing seasons are longer than 330 days (e.g., wheat in large parts of Russia), except for sugarcane, which is recorded to grow all year round in MIRCA2000. Finally, we use LPJmL data to fill remaining areas globally with climatedriven rule-based estimates covering a large subset of Priority 1 and 2 crops.

To estimate growing season length, we use harvest dates from the same data set selected for planting dates. In order 
to estimate the maturity date (which characterizes crop varieties) from the harvest date, we correct for crop-specific times between harvest and maturity, assuming that maturity in models refers to the development stage in which the green leaf area index is zero ("fully ripe"; BBCH code 89$)^{4}$. Where no information on differences between harvest and maturity dates could be found, we assume no difference (Table 11 contains details by crop).

In regions where no crop calendar supplies data, we use simulated phenology from LPJmL. Here, we mark planting dates as unreasonable if planting in cool regions occurs before day 90 or after day 274 in the Northern Hemisphere or between days 152 and 304 in the Southern Hemisphere. We define cool regions as those in which the annual mean of monthly maximum temperatures according to the WATCH data average for $1991-2000$ is only $3{ }^{\circ} \mathrm{C}$ above the cropspecific base temperature. In these areas, GGCMI modelers can choose any planting date or skip the simulation as results will not be evaluated. Generally, all anticipated analyses will consider current cropland areas only, for which data are generally available from crop calendars. Data filling with rulebased algorithms is only meant to harmonize assumptions among models and to enable standard all-crops-everywhere simulations.

We also mask harvest dates as unreasonable where crops in regions filled with rule-based LPJmL data do not reach maturity within a prescribed crop-specific maximum growing season length, where crops die after less than 60 days, where freezing (Tmin of WATCH data average for 1991-2000 below $0^{\circ} \mathrm{C}$ ) occurs in the month prior to maturity, or where planting dates are unreasonable.

If the LPJmL growing season occurs in very hot seasons (defined as those for which Tmax of WATCH data average for 1991-2000 in one of the growing season months is $>38^{\circ} \mathrm{C}$ ), we assume that the growing season of temperate cereals (barley, rye, wheat) is offset by $6,+3$ or -3 months to avoid the heat. Offsets are tested in this sequence and the first that actually reduces maximum monthly temperatures to at least below $36^{\circ} \mathrm{C}$ is selected. Avoidance of heat is not part of the rules implemented in LPJmL (Waha et al., 2012) and may imply that corrected sowing does not happen during the wettest season. Since these areas are not currently cropped (otherwise there would be crop calendar data), it seems justifiable to correct sowing dates for cooler seasons for harmonized simulation data.

SAGE calendar data are uniform within administrative units. If the SAGE data set suggests that planting in currently unused grid cells would occur in autumn but mean monthly temperatures are already below $5^{\circ} \mathrm{C}$, we correct planting dates for the planting of spring varieties. For this correction, we select the first month, starting in January for the Northern Hemisphere and in July for the Southern Hemisphere, in

\footnotetext{
${ }^{4}$ http://en.wikipedia.org/wiki/BBCH-scale_cereals
}

which average monthly temperatures (Tas of WATCH data average for 1991-2000) rise above $5^{\circ} \mathrm{C}$.

The $\mathrm{R}$ processing script that we used to generate these data are available in the appendix and in the GGCMI software repository at https://github.com/RDCEP/ggcmi/.

\subsubsection{Implementation instructions for growing season dates}

GGCMI modelers should implement planting dates per grid cell, per crop, and per irrigation system (purely rain-fed vs. irrigated) either directly or with a given flexibility within model-specific planting windows. In regions in which the harmonized planting dates as supplied here are masked as unreasonable, crop modelers may either set planting dates to any date or simply skip simulations, whichever is easier to implement. These data will not be considered in GGCMI analyses.

Crop variety parameters (e.g., required growing degree days to reach maturity, vernalization requirements, photoperiodic sensitivity) should be adjusted as much as possible to roughly match reported maturity dates supplied here for the average of the period 1991-2000. In regions in which harvest dates are masked as unreasonable, modelers should parameterize their fastest maturing crop variety as these stand best chances to reach maturity at all.

\subsection{Harmonized fertilizer inputs}

We supply average annual nitrogen (N-equivalent), phosphorus $\left(\mathrm{P}_{2} \mathrm{O}_{5}\right.$-equivalent), and potassium $\left(\mathrm{K}_{2} \mathrm{O}\right.$-equivalent $)$ application rates $\left(\mathrm{kg} \mathrm{ha}^{-1} \mathrm{yr}^{-1}\right)$ for 15 crops and all locations. We supply crop-specific fertilization rates for the Priority 1 crops (Table 1), a broad set of Priority 2 crops (cassava, cotton, groundnuts, millet, potatoes, rapeseed, sorghum, sugar beets, sugarcane, sunflower), and for one perennial crop, coffee. Fertilizer data are based on published data on mineral fertilizers and manure applications (Mueller et al., 2012; Potter et al., 2010; Foley et al., 2011). These data are available for currently cropped areas and have been extrapolated in space to cover the entire land surface.

\subsubsection{Methodology}

We compiled and harmonized fertilizer data in a four-step procedure. First, we disaggregated manure data into cropspecific application rates. This was done by assigning a proportion of the manure nutrient production from Potter et al. (2010) to croplands as outlined in Foley et al. (2011). Of manure applied to croplands, crop-specific application was determined by dividing manure application in each grid cell between all crops present in the grid cell, in proportion to the harvested area of each crop.

We aggregate data from the original 5 arc minute resolution to the GGCMI simulation grid of $0.5^{\circ} \times 0.5^{\circ}$. The political units in the original mineral fertilizer data set differ 
Table 9. Historical climate forcing data sets for Phase 1.

\begin{tabular}{|c|c|c|c|c|c|}
\hline Data set & Reanalysis & Years & Resolution* & Bias-correction target & Notes \\
\hline WATCH (WFD) & ERA-40 & $1958-2001$ & $2.5^{\circ}\left(0.5^{\circ}\right)$ & GPCC & $\begin{array}{l}\text { WATCH Forcing Data (WFD) (Weedon } \\
\text { et al., 2011) }\end{array}$ \\
\hline WFDEI & ERA-Interim & $\begin{array}{l}1979-2010 \\
(\text { GPCC) } \\
1979-2012 \\
(\text { CRU) }\end{array}$ & $0.75^{\circ}\left(0.5^{\circ}\right)$ & $\begin{array}{l}\text { GPCC and CRU as sep- } \\
\text { arate versions }\end{array}$ & $\begin{array}{l}\text { Versions with different bias tar- } \\
\text { get are denoted WFDEI.GPCC and } \\
\text { WFDEI.CRU (Weedon et al., 2014) }\end{array}$ \\
\hline GRASP & JRA-25 \& ERA-40 & $1961-2010$ & $1.125^{\circ}\left(1.125^{\circ}\right)$ & $\begin{array}{l}\text { CRU-TS3.10, CL1.0 } \\
\text { wind, SRB solar }\end{array}$ & $\begin{array}{l}\text { Mean/max/min } 2 \mathrm{~m} \text { temp, precip, so- } \\
\text { lar, vap pres., } 10 \mathrm{~m} \text { wind (Iizumi et al., } \\
\text { 2014) }\end{array}$ \\
\hline AgMERRA & MERRA & $1980-2010$ & $\begin{array}{l}0.5^{\circ} \times 0.66^{\circ} \\
\left(0.5^{\circ} / 0.25^{\circ}\right)\end{array}$ & $\begin{array}{l}\text { CRU/GPCC/UDel/ } \\
\text { SRB/Satellite precip }\end{array}$ & $\begin{array}{l}\text { Precip: CMORPH, PERSIANN, } \\
\text { TRMM. Out: Tmax/min, precip, solar, } \\
\text { RHS at Tmax, wind (Ruane et al., } \\
\text { 2015) }\end{array}$ \\
\hline AgCFSR & CFSR & 1980-2010 & $\begin{array}{l}0.3^{\circ} \\
\left(0.5^{\circ} / 0.25^{\circ}\right)\end{array}$ & Same as AgMERRA & $\begin{array}{l}\text { Same target as AgMERRA (Ruane et } \\
\text { al., 2015) }\end{array}$ \\
\hline \multicolumn{6}{|c|}{ Pure reanalysis products (for evaluation of the effects of bias-correction) } \\
\hline CFSR & CFSR & 1979-2012 & $0.3^{\circ}$ (NA) & NA & Pure reanalysis (Saha et al., 2010) \\
\hline ERA-I & ERA-I & 1979-2012 & $0.75^{\circ}(\mathrm{NA})$ & NA & Pure reanalysis (Dee et al., 2011) \\
\hline
\end{tabular}

for each crop type and cover current crop-specific growing areas, up to 473 units for the maize nitrogen fertilizer data (Mueller et al., 2012). Therefore we harmonized the administrative boundary units across crop and nutrient types for the interpolation procedure here. Data on manure application (Potter et al., 2010) have resolution finer than political units, as they are based off a gridded livestock data set. Thus, the manure nutrient maps were simply aggregated to each of the 372 administrative units as an area-weighted average.

In a third step, we harmonized the reference units between organic and inorganic fertilizers (manure). Original manure data are reported in terms of atomic nitrogen $(\mathrm{N})$ and phosphorus (P) and assumed to contain no potassium (Potter et al., 2010), whereas inorganic fertilizer data are reported as $\mathrm{N}$, phosphate $\left(\mathrm{P}_{2} \mathrm{O}_{5}\right)$, and potassium oxide $\left(\mathrm{K}_{2} \mathrm{O}\right)$. The conversion from $\mathrm{P}$ manure to $\mathrm{P}_{2} \mathrm{O}_{5}$ is based on atomic masses

$\mathrm{P}_{2} \mathrm{O}_{5}-$ eq. $=\mathrm{P} / 31 \times(31 \times 2+5 \times 16)$.

Nutrients from manure are generally less available to plants than mineral fertilizers. We assume $60 \%$ of applied $\mathrm{N}$-manure and $75 \%$ of applied P-manure to be plant available (Rosen and Bierman, 2005).

In the final step, we extrapolated fertilizer application rates to currently uncultivated land. The original data on mineral fertilizers (Mueller et al., 2012) cover only cropspecific harvested areas. First, we assigned the national average nutrient-specific fertilizer rate (area-weighted) to all administrative units that do not apply any mineral fertilizer or manure in the original data but are within a country that does reporting fertilizer application. Second, for all other coun- tries that do not currently apply fertilizer to grow the specific crop, we attributed estimated nutrient-specific application rates by averaging fertilizer application rates over the corresponding income level group. We base income level groups on the World Bank's definition to classify countries by income level: economies are divided according to 2012 gross national income per capita, calculated using the World Bank Atlas method ${ }^{5}$. The groups are as follows: low income, USD 1035 or less; lower middle income, USD 1036-4085; upper middle income, USD 4086-12 615; and high income, USD 12616 or more. We averaged fertilizer application rates for all countries with fertilizer applications of larger than zero within the income level group and applied those rates to all countries without fertilizer data within that group.

\subsubsection{Implementation instructions}

All fertilizer data supplied here should be treated as mineral fertilizer; organic fertilizer (manure) has been reduced to account for limited plant availability and combined with data on inorganic fertilizer applications.

\subsection{Other data and parameter recommendations}

In addition to management drivers, we harmonize historical $\mathrm{CO}_{2}$ levels based on the Mauna Loa Observatory time series (Thoning et al., 1989). We also provide instructions for how to measure growing seasons, and provide guidance on pa-

\footnotetext{
${ }^{5}$ http://go.worldbank.org/IEH2RL06U0, last access: 1 November 2013
} 


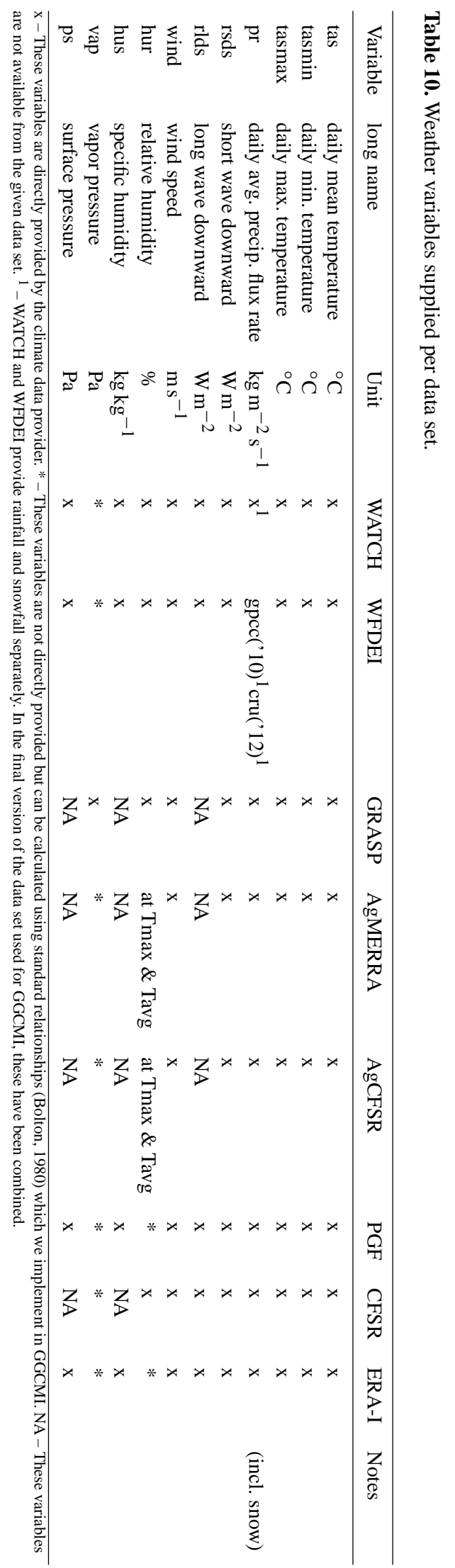

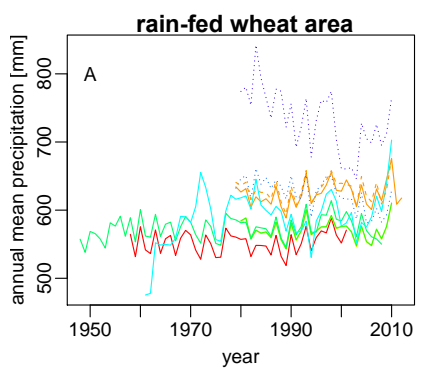
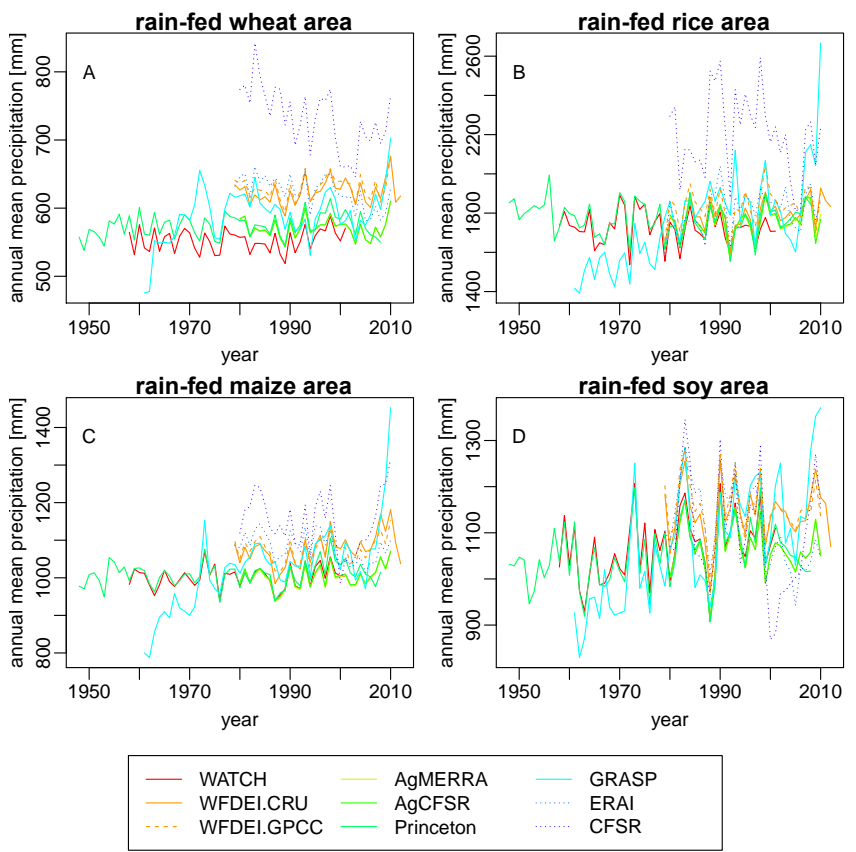

Figure 2. Area-weighted mean of annual precipitation $\left[{ }^{\circ} \mathrm{C}\right]$ for cropping areas for rain-fed wheat (a), rice (b), maize (c), and soy (d).

rameter choices for automatic irrigation algorithms (where applicable).

\subsection{Data format conventions of input data}

All input data are supplied in gridded format at $0.5^{\circ} \times 0.5^{\circ}$ spatial resolution in a compressed NetCDF4 file format. Weather data are available at daily time steps and at 3-hourly values for WFDEI (which is required for some participating land-surface models). Management data are available for only one time period and are assumed to apply for all historic time periods since data are lacking in changes in management over time (all comparisons are done between detrended observation and simulation time series, which greatly reduces, but certainly does not eliminate the effect of changes in management practices and technology over time).

\section{Evaluation data sets and procedures}

\subsection{Historical yield data}

We will use three yield data products at multiple scales to evaluate our simulation outputs, Iizumi (Iizumi et al., 2014), Ray (Ray et al., 2012), and FAOSTAT (FAOSTAT data, 2013). Iizumi (Fig. 4, left) provides a hybrid of national statistics and satellite-derived normalized difference vegetation index (NDVI) at a nominal resolution of $1.125^{\circ}$, covering maize, soy, wheat, and rice, and spanning 1982-2006. Ray (Fig. 4, right) covers the same four crops using national, 
Table 11. Combination of crop calendar data in GGCMI data sets.

\begin{tabular}{|c|c|c|c|c|}
\hline GGCMI crop & MIRCA2000 & SAGE & LPJmL & Days maturity to harvest \\
\hline Barley & Barley & Barley spring+winter & Wheat & $7^{\mathrm{a}}$ \\
\hline Cassava & Cassava & Cassava & Cassava & Assuming $0^{\mathrm{b}}$ \\
\hline Groundnuts & Groundnuts & Groundnuts & Groundnuts & $0^{\mathrm{c}}$ \\
\hline Maize & Maize & Maize & Maize & $1-28^{\mathrm{d}}$, here 21 \\
\hline Millet & Millet & Millet & Millet & Assuming 0 \\
\hline Potatoes & Potatoes & Potatoes & Sugar beets & Assuming 0 \\
\hline $\begin{array}{l}\text { Pulses (dry bean, } \\
\text { field peas) }\end{array}$ & Pulses & Pulses & Pulses & Assuming 0 \\
\hline Rapeseed & Rapeseed & Rapeseed, winter & Rapeseed & Same as wheat $=7$ \\
\hline Rice & Rice & Rice & Rice & $0^{\mathrm{e}}$ or $8-12^{\mathrm{f}}$, here $^{\mathrm{a}}$ \\
\hline Rye & Rye & Rye, winter & Wheat & $7^{\mathrm{a}}$ \\
\hline Sorghum & Sorghum & Sorghum & Millet & $0^{\mathrm{g}}$ \\
\hline Soybeans & Soybeans & Soybeans & Soybeans & $7-21^{\mathrm{h}}$ here 21 \\
\hline Sugar beets & Sugar beets & Sugar beets & Sugar beets & Assuming 0 \\
\hline Sugarcane & Sugarcane & NA & Sugarcane & Assuming 0 \\
\hline Sunflower & Sunflower & Sunflower & Sunflower & $0^{\mathrm{i}}$ \\
\hline Wheat & Wheat & Wheat, spring+winter & Wheat & $3^{\mathrm{j}}$ to $8^{\mathrm{k}}$, here 7 \\
\hline
\end{tabular}

\footnotetext{
a Assuming quick harvests for barley, rice, rye, and wheat as they are all threatened by pre-harvest sprouting (see, e.g., http://www.dpi.nsw.gov.au/data/assets/pdf_file/0010/445636/farrer_oration_1981_nf_derera.pdf) but allowing some time to dry after full maturity. ${ }^{b}$ Can be anything from 0 days to up to 6 months, harvest on demand.

${ }^{\mathrm{c}}$ http://www.interaide.org/pratiques_old/pages/agro/3cultures/Phalombe_Mlwi_crop_management_2010.pdf, p. 8.

${ }^{\mathrm{d}} \mathrm{http}: / / \mathrm{www}$.smartgardener.com/plants/4159-corn-cherokee-white-flour/harvesting.

e http://agris.fao.org/agris-search/search/display.do?f=19902FPH3FPH90013.xml3BPH8811720.

${ }^{\mathrm{f}} \mathrm{http}: / /$ www.interaide.org/pratiques_old/pages/agro/3cultures/Phalombe_Mlwi_crop_management_2010.pdf, p. 13.

$\mathrm{g}$ http://www.interaide.org/pratiques_old/pages/agro/3cultures/Phalombe_Mlwi_crop_management_2010.pdf, p. 14

${ }^{\mathrm{h}} \mathrm{http} / / /$ agris.fao.org/agris-search/search/display.do?f=20092FJP2FJP0932.xml3BJP2009005739.

${ }^{\mathrm{i}} \mathrm{http} / / / \mathrm{www}$. interaide.org/pratiques_old/pages/agro/3cultures/Phalombe_Mlwi_crop_management_2010.pdf, p. 12.

$\mathrm{j}$ http://agris.fao.org/agris-search/search/display.do?f=20092FJP2FJP0938.xml3BJP2009007527. ${ }^{\mathrm{k}}$ http://www.dwd.de/bvbw/appmanager/bvbw/ dwdwwwDesktop? nfpb=true windowLabel=T94008\&_urlType=action\&_pageLabel=dwdwww_klima_umwelt phaenologie shows that there are 16 days between "hard dough" stage (BBCH87) and harvest in Germany, and http://www.dwd.de/bvbw/generator/DWDWWW/Content/Landwirtschaft/Dokumentation/ AgroProg/Kornfeuchte,templateId=raw,property=publicationFile.pdf/Kornfeuchte.pdf shows that there are about 8 days between "hard dough" and "fully ripe" (BBCH89) stages, so that the difference between "fully ripe" and harvest is 8 days as well.
}

sub-national, and sub-subnational statistics, spanning 19612008, and provided at a nominal resolution of 5 arc minutes by distributing yield statistics from administrative units to grid cells evenly based on the approximate distribution of crop areas in the unit, without any proxy measurements of the relative distribution of attained yields. To fill in the gaps for crops and years that are not available in these first two data sets, we will compare aggregated simulation outputs at the national level directly with statistics from FAOSTAT.

\subsection{Open-source processing and evaluation pipeline}

In order to ensure consistency and encourage consensus in GGCMI products, we are developing all output processing software utilities within an open software repository available at https://github.com/RDCEP/ggcmi/. Additionally, we permanently archive the intermediate and final results of each step in the output processing pipeline on the GGCMI data servers. These data will be made available along with the data supplied by GGCMI modeling groups at the time of public release. The key stages of the pipeline are described in Sects. 4.2.1-4.2.4.

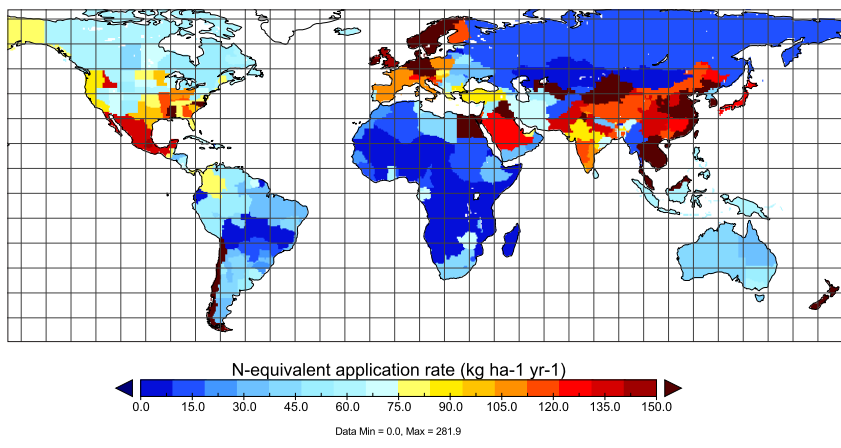

Figure 3. N-equivalent application rate of nitrogen fertilizers for the production of wheat.

\subsubsection{Aggregation}

All simulated data are first aggregated up to administrative and environmental boundaries, including state/province $\left(\mathrm{GADM}^{6}\right.$ level 1$)$, country (GADM level 0 ), river basins and food producing units (FPUs; river basins crossed with coun-

\footnotetext{
${ }^{6} \mathrm{http}: / / g a d m . o r g /$
} 
A) Wheat Yield - lizumi et al. 2013 (t/ha)

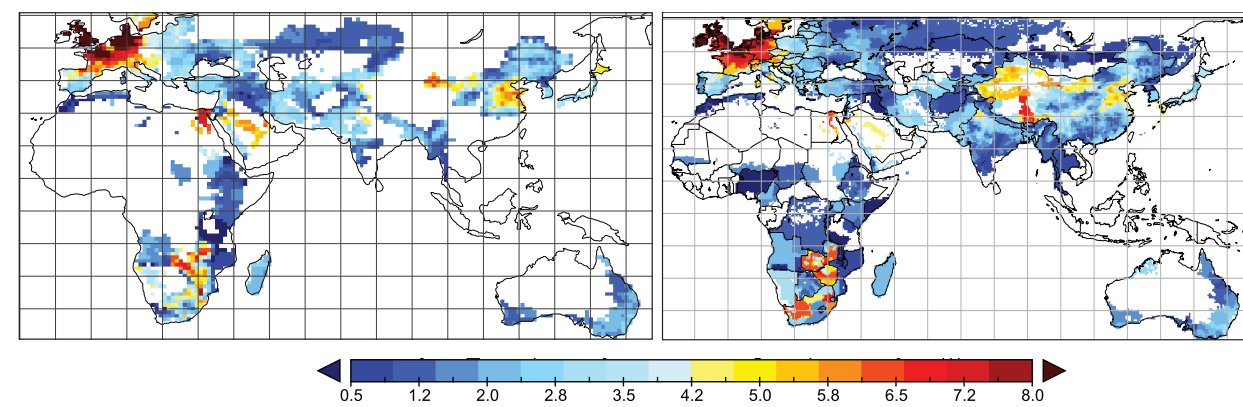

Figure 4. Example of historical evaluation data for year 2000 wheat yields from (a) Iizumi et al. (2013) (at 1.125 spatial resolution) and (b) Ray et al. (2012) (aggregated from 5 arc minutes to $0.5^{\circ}$ ).
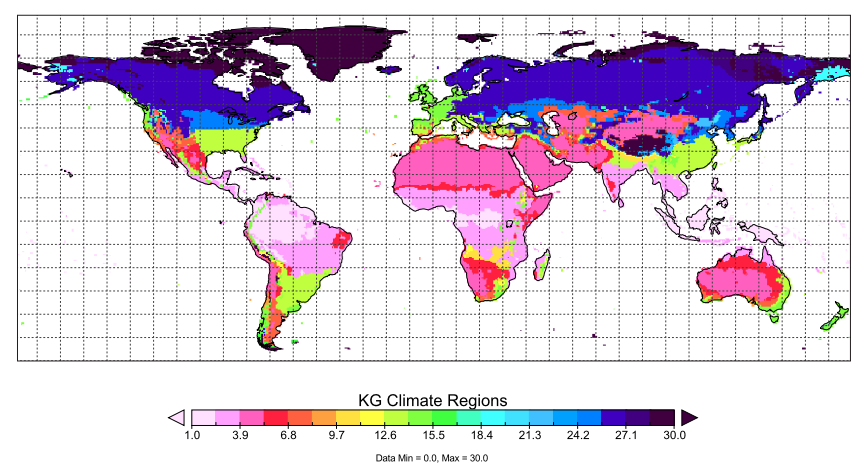

Figure 5. Example of a global Köppen-Geiger climate classification.

tries (Cai and Rosegrant, 2002)), Köppen-Geiger climate regions (Peel et al., 2007) (example shown in Fig. 5), and largescale continental or sub-continental regions.

\subsubsection{De-trending}

In order to compare FAOSTAT observations with simulation results, we must remove trends from the statistics. As there are several methods to remove trends from observed data and no one method works best in all situations, we employ four distinct de-trending methods: we take (i) the linear or (ii) quadratic trends from a least squares regression (Fig. 6, right), (iii) we take a 7-year moving mean trend, and (iv) we calculate the fraction first differences, $Y_{t} / Y_{t-1}-1$, of the series and remove a linear trend (Fig. 6, right). All conclusions and results are then checked for robustness against all the detrending method used.

\subsubsection{Multi-metric evaluation}

GGCMI uses a varied approach to evaluate model outputs over the evaluation period, comparing reference data and simulations using a number of metrics and methodologies. In preliminary analysis, metrics evaluated include the time series correlation, root mean square error, ratio of simulated and observed coefficients of variation, and the top and bottom hit rates (number of years in the top and bottom quintile of the observation series that are reproduced in the simulated series). The metrics are formalized in the output processing pipeline in a set of multi-dimensional metric files, which are provided along with a plotting application that produces twodimensional cross sections by selecting, averaging, or optimizing over any combination of dimensions (an example array is shown in Fig. 7).

\subsubsection{Multi-model ensembles}

In the final processing step, we aim to produce multi-model ensemble versions of the output to evaluate, for example, how well the ensemble performs relative to individual models, highlighting individual model skill and deficiencies vs. model community skills and deficiencies. This step uses the multi-metric files to produce versions of the simulated variables that aggregate all of the models into various combinations. Ensembles range in complexity from simple averages (all models weighted equally) to weighted averages using one or more evaluation metric, and from all models included in the average to the inclusion of only the top-performing model. Finally, we produce evaluation multi-metric files for the ensemble combinations to easily facilitate comparison of the ensemble measurements with individual models. This will be the basis for identifying central processes in models that are responsible for differences in model performance as well as general model deficiencies that require improvements in all models and in understanding. This phase will likely require additional simulations with modified models.

\section{GGCMI data archive and crediting}

GGCMI computing and data services are housed at the University of Chicago Research Computing Center (RCC) and the German Climate Computing Center (DKRZ). GGCMI will host an archive of all project inputs and outputs and will work continuously with research and stakeholder communi- 
A) Historical Maize Yield (t/ha)

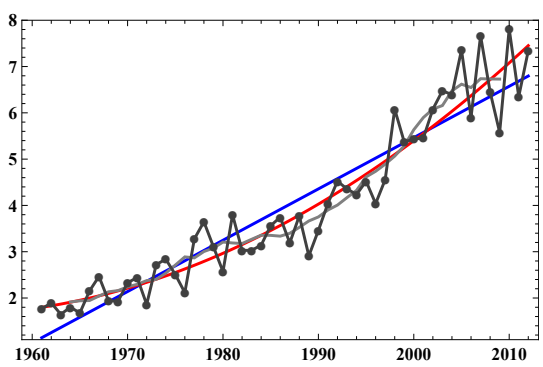

B) Historical Maize Yield (fractional first difference)

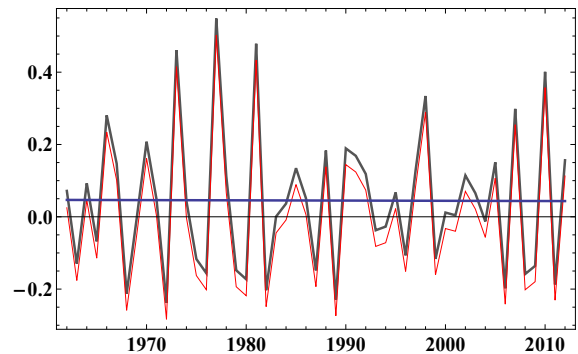

Figure 6. (a) FAOSTAT yield for maize in Argentina (solid line and points) with the linear (blue) and quadratic (red) best-fits and 7-year moving average (gray). (b) Fractional first difference of maize yields in Argentina (gray), the linear trend (blue line) and the fractional first difference with the trend removed (red).
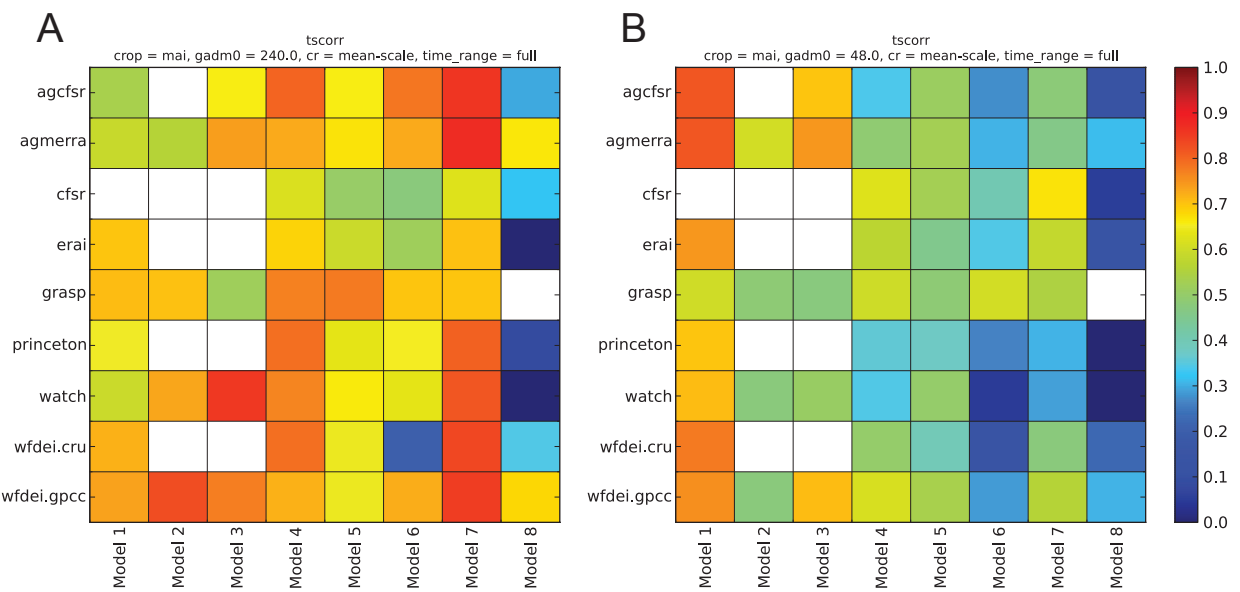

Figure 7. Examples of cross sections of the multi-metric evaluation array for the top two maize-producing countries - the United States (a) and China (b). Plot shows time series correlations for eight different crop models run ( $x$ axis) with nine different climate forcing data sets ( $y$ axis). For each model/climate combination, the best metric value among the scenarios (default, fullharm, and harmnon) and de-trending methods (linear, quadratic, moving mean, and trend-removed fraction first difference) are shown.

ties, for example, through engagement processes established as part of frequent regional and global workshops hosted by AgMIP, to improve archive access and usability. During each phase of the project (i.e., before the public launch of the resulting archive), all inputs and outputs generated belong to the GGCMI as a team (i.e., all GGCMI modelers) and must not be used, distributed, presented, or published in any individual or selected study without the consent of the group of contributing GGCMI modelers. During this time, presentations and publications will be led by GGCMI team members and will be coordinated through the GGCMI coordinators. The publications must acknowledge each individual contribution, including providers of not publicly available input or reference data, via co-authorship or other agreed acknowledgement.

Because GGCMI acts as the sectoral coordinator for crop modeling in Phase 2 of the ISI-MIP project (ISIMIP2), we have designed the GGCMI protocols to overlap with (planned) ISI-MIP2 simulations as closely as possible. Upon the data submission deadline as defined by ISI-MIP2,
GGCMI data will automatically be transferred to ISI-MIP2, unless otherwise specified by participating modelers. At this time, GGCMI modelers become ISI-MIP2 participants and additional restrictions or specifications for data availability, as negotiated between ISI-MIP2 and GGCMI coordinators and modelers, may apply at this time.

\section{Discussion}

The core outcome of GGCMI is the creation and maintenance of an international community of modelers focusing on climate impacts and relationships to food security, resources, economics, land-use change, and climate feedbacks at continental and global scales. As has been amply demonstrated in processes like the Coupled Model Intercomparison Project (CMIP) (Taylor et al., 2012), the Energy Modeling Forum (Weyant et al., 2006), AgMIP projects such as the wheat pilot (Asseng et al., 2013), and the ISI-MIP Fast Track recently completed (Warszawski et al., 2014; Rosenzweig et 
al., 2014; Elliott et al., 2014a; Nelson et al., 2014), the bringing together of modelers working independently on complex dynamic phenomena to compare and synthesize outputs can generate substantive insights and innovations that are not generally possible otherwise. A key observation from the AgMIP/ISI-MIP Fast Track and other recent model intercomparisons (Rosenzweig et al., 2014; Nelson et al., 2014; Challinor et al., 2014), and a key motivation for GGCMI, is the importance of harmonization of input data and assumptions.

Each phase of GGCMI will include planning, simulation, analysis, and publication components that will build on the inputs, science, and deliverables of the previous phase. In Phase 2, GGCMI participants will conduct a multidimensional sensitivity study of model response to carbon dioxide, temperature, water, and nitrogen (CTWN) organized around a set of simulations driven by perturbed versions of the historical and harmonized data products prepared in Phase 1. Results will be used both to analyze model sensitivity and to develop high-resolution multi-dimensional response surfaces that can be aggregated into arbitrary administrative or environmental boundaries and will be tested for suitability as efficient multi-model emulators. In Phase 3, GGCMI participants will conduct a comprehensive assessment of climate vulnerabilities, impacts, and adaptations using a new set of future climate forcings from CMIP5 and Coordinated Regional Climate Downscaling Experiment (CORDEX) and a detailed set of adaptation scenarios developed in the AgMIP Representative Agricultural Pathways (RAPs) framework. GGCMI also builds on other existing AgMIP projects, such as the Coordinated Climate-Crop Modeling Project (Ruane et al., 2014), and cross-cutting themes such as uncertainty and spatial scaling/aggregation.

During GGCMI's 3-year duration, our aim is for the community to create a new standard for research on global change vulnerabilities, impacts, and potential adaptations. Data products, analyses and insights are to be published in peer-reviewed scientific journals and will thus be accessible to the scientific community. Due to the open and accessible structure of the project and its data distribution architecture, we expect important scientific outcomes and deliverables to evolve and develop during and well beyond the planned project lifetime. GGCMI leverages and relies on the contributions of many partners that typically lack funding for this project. However, the tremendous enthusiasm that this project has generated among participants and user communities makes us confident that GGCMI will succeed in accomplishing its stated goals - and, with high likelihood, greatly surpass those goals. In addition, close partnership with the AgMIP and ISI-MIP networks and the active participation of leaders from those groups, will help ensure that GGCMI is highly visible within and beyond the scientific community. The GGCMI team will also work with potential end users to facilitate usage of GGCMI results downstream in economic models and globally and regionally integrated assessments.
For this purpose we are developing several use cases for the existing Fast Track archive (Nelson et al., 2014) and working with economic modeling communities such as the Energy Modeling Forum (EMF) and the Global Trade Analysis Project (GTAP) ${ }^{7}$ and actively seek funding for GGCMI activities and cooperation with other groups.

The standardized, protocol-based model intercomparison described here will be the basis for a clear analysis of model skills and deficiencies, identification and reduction of crop model uncertainties, and identification of future development paths to improve models and assessments. Clearly, more work than is envisioned here is needed in analyzing and improving crop modeling skills for gridded large-scale applications. Still, the first phase of GGCMI will provide a solid basis for future work by providing not only standardized inputs and reference data but also open-access data processing and analysis tools. During this first part of the project, by identifying the main sources of uncertainty and model disagreement, we expect that key conditions for the next phase of analysis will take shape. We hope to support all large-scale crop modeling efforts with the insights and analysis tools that are produced in GGCMI, and we invite all agricultural scientists to contribute to the development and framing of the next phases of the project and protocols.

Acknowledgements. J. Elliott acknowledges financial support from the National Science Foundation under grants SBE-0951576 and GEO-1215910. C. Müller acknowledges financial support from the KULUNDA project (01LL0905L) and the FACCE MACSUR project (031A103B) funded through the German Federal Ministry of Education and Research (BMBF). Computing and data resources provided through the University of Chicago Research Computing Center.

Edited by: A. B. Guenther

\section{References}

Asseng, S., Ewert, F., Rosenzweig, C., Jones, J. W., Hatfield, J. L., Ruane, A. C., Boote, K. J., Thorburn, P. J., Rotter, R. P., Cammarano, D., Brisson, N., Basso, B., Martre, P., Aggarwal, P. K., Angulo, C., Bertuzzi, P., Biernath, C., Challinor, A. J., Doltra, J., Gayler, S., Goldberg, R., Grant, R., Heng, L., Hooker, J., Hunt, L. A., Ingwersen, J., Izaurralde, R. C., Kersebaum, K. C., Müller, C., Naresh Kumar, S., Nendel, C., O/'Leary, G., Olesen, J. E., Osborne, T. M., Palosuo, T., Priesack, E., Ripoche, D., Semenov, M. A., Shcherbak, I., Steduto, P., Stockle, C., Stratonovitch, P., Streck, T., Supit, I., Tao, F., Travasso, M., Waha, K., Wallach, D., White, J. W., Williams, J. R., and Wolf, J.: Uncertainty in simulating wheat yields under climate change, Nat. Clim. Change, 3, 827-832, doi:10.1038/NCLIMATE1916, 2013.

Balkovič, J., van der Velde, M., Schmid, E., Skalský, R., Khabarov, N., Obersteiner, M., Stürmer, B., and Xiong, W.: Pan-European

\footnotetext{
${ }^{7}$ https://www.gtap.agecon.purdue.edu/
} 
crop modelling with EPIC: Implementation, up-scaling and regional crop yield validation, Agricultural Systems, 120, 61-75, doi:10.1016/j.agsy.2013.05.008, 2013.

Bolton, D.: The Computation of Equivalent Potential Temperature, Mon. Weather Rev., 108, 1046-1053, doi:10.1175/15200493(1980)108<1046:TCOEPT>2.0.CO;2, 1980.

Bondeau, A., Smith, P. C., Zaehle, S., Schaphoff, S., Lucht, W., Cramer, W., Gerten, D., Lotze-Campen, H., Müller, C., Reichstein, M., and Smith, B.: Modelling the role of agriculture for the 20th century global terrestrial carbon balance, Glob. Change Biol., 13, 679-706, doi:10.1111/j.13652486.2006.01305.x, 2007.

Cai, X. M. and Rosegrant, M. W.: Global water demand and supply projections part - 1. A modeling approach, Water Int., 27, 159$169,2002$.

Challinor, A. J., Wheeler, T. R., Craufurd, P. Q., Slingo, J. M., and Grimes, D. I. F.: Design and optimisation of a large-area processbased model for annual crops, Agr. Forest Meteorol., 124, 99120, 2004.

Challinor, A. J., Watson, J., Lobell, D. B., Howden, S. M., Smith, D. R., and Chhetri, N.: A meta-analysis of crop yield under climate change and adaptation, Nat. Clim. Change, 4, 287-291, doi:10.1038/nclimate2153, 2014.

Dee, D. P., Uppala, S. M., Simmons, A. J., Berrisford, P., Poli, P., Kobayashi, S., Andrae, U., Balmaseda, M. A., Balsamo, G., Bauer, P., Bechtold, P., Beljaars, A. C. M., van de Berg, L., Bidlot, J., Bormann, N., Delsol, C., Dragani, R., Fuentes, M., Geer, A. J., Haimberger, L., Healy, S. B., Hersbach, H., Hólm, E. V., Isaksen, L., Kållberg, P., Köhler, M., Matricardi, M., McNally, A. P., Monge-Sanz, B. M., Morcrette, J. J., Park, B. K., Peubey, C., de Rosnay, P., Tavolato, C., Thépaut, J. N., and Vitart, F.: The ERA-Interim reanalysis: configuration and performance of the data assimilation system, Q. J. Roy. Meteorol. Soc., 137, 553597, doi:10.1002/qj.828, 2011.

de Noblet-Ducoudre, N., Gervois, S., Ciais, P., Viovy, N., Brisson, N., Seguin, B., and Perrier, A.: Coupling the Soil-VegetationAtmosphere-Transfer Scheme ORCHIDEE to the agronomy model STICS to study the influence of croplands on the European carbon and water budgets, Agronomie, 24, 397-407, 2004.

Deryng, D., Sacks, W. J., Barford, C. C., and Ramankutty, N.: Simulating the effects of climate and agricultural management practices on global crop yield, Global Biogeochem. Cy., 25, GB2006, doi:10.1029/2009GB003765, 2011.

Deryng, D., Conway, D., Ramankutty, N., Price, J., and Warren, R.: Global crop yield response to extreme heat stress under multiple climate change futures, Environ. Res. Lett., 9, 034011, doi:10.1088/1748-9326/9/3/034011, 2014.

Drewniak, B., Song, J., Prell, J., Kotamarthi, V. R., and Jacob, R.: Modeling agriculture in the Community Land Model, Geosci. Model Dev., 6, 495-515, doi:10.5194/gmd-6-495-2013, 2013.

Elliott, J., Deryng, D., Müller, C., Frieler, K., Konzmann, M., Gerten, D., Glotter, M., Flörke, M., Wada, Y., Best, N., Eisner, S., Fekete, B. M., Folberth, C., Foster, I., Gosling, S. N., Haddeland, I., Khabarov, N., Ludwig, F., Masaki, Y., Olin, S., Rosenzweig, C., Ruane, A. C., Satoh, Y., Schmid, E., Stacke, T., Tang, Q., and Wisser, D.: Constraints and potentials of future irrigation water availability on agricultural production under climate change, P. Natl. Acad. Sci., 111, 3239-3244, doi:10.1073/pnas.1222474110, 2014a.
Elliott, J., Kelly, D., Chryssanthacopoulos, J., Glotter, M., Jhunjhnuwala, K., Best, N., Wilde, M., and Foster, I.: The parallel system for integrating impact models and sectors, Environ. Model. Softw., 62, 509-516, doi:10.1016/j.envsoft.2014.04.008, online first, 2014b.

FAOSTAT data: available at: http://faostat.fao.org/ (last access: 1 November 2013), 2013.

Foley, J. A., Ramankutty, N., Brauman, K. A., Cassidy, E. S., Gerber, J. S., Johnston, M., Mueller, N. D., O'Connell, C., Ray, D. K., West, P. C., Balzer, C., Bennett, E. M., Carpenter, S. R., Hill, J., Monfreda, C., Polasky, S., Rockstrom, J., Sheehan, J., Siebert, S., Tilman, D., and Zaks, D. P. M.: Solutions for a cultivated planet, Nature, 478, 337-342, doi:10.1038/nature10452, 2011.

Gueneau, A., Schlosser, C. A., Strzepek, K. M., Gao, X., and Monier, E.: CLM-AG: An Agriculture Module for the Community Land Model version 3.5, MIT Joint Program on the Science and Policy of Global Change, 2012.

Iizumi, T., Yokozawa, M., Sakurai, G., Travasso, M. I., Romanernkov, V., Oettli, P., Newby, T., Ishigooka, Y., and Furuya, J.: Historical changes in global yields: major cereal and legume crops from 1982 to 2006, Global Ecol. Biogeogr., doi:10.1111/geb.12120, online first, 2013.

Iizumi, T., Yokozawa, M., Sakurai, G., Travasso, M. I., Romanernkov, V., Oettli, P., Newby, T., Ishigooka, Y., and Furuya, J.: Historical changes in global yields: major cereal and legume crops from 1982 to 2006, Global Ecol. Biogeogr., 23, 346-357, doi:10.1111/geb.12120, 2014.

Izaurralde, R. C., Williams, J. R., McGill, W. B., Rosenberg, N. J., and Jakas, M. C. Q.: Simulating soil C dynamics with EPIC: Model description and testing against long-term data, Ecol. Model., 192, 362-384, 2006.

Jones, J. W., Hoogenboom, G., Porter, C. H., Boote, K. J., Batchelor, W. D., Hunt, L. A., Wilkens, P. W., Singh, U., Gijsman, A. J., and Ritchie, J. T.: The DSSAT cropping system model, Eur. J. Agron., 18, 235-265, 2003.

Keating, B. A., Carberry, P. S., Hammer, G. L., Probert, M. E., Robertson, M. J., Holzworth, D., Huth, N. I., Hargreaves, J. N. G., Meinke, H., Hochman, Z., McLean, G., Verburg, K., Snow, V., Dimes, J. P., Silburn, M., Wang, E., Brown, S., Bristow, K. L., Asseng, S., Chapman, S., McCown, R. L., Freebairn, D. M., and Smith, C. J.: An overview of APSIM, a model designed for farming systems simulation, Eur. J. Agron., 18, 267-288, doi:10.1016/S1161-0301(02)00108-9, 2003.

Levis, S., Bonan, G. B., Kluzek, E., Thornton, P. E., Jones, A., Sacks, W. J., and Kucharik, C. J.: Interactive Crop Management in the Community Earth System Model (CESM1): Seasonal Influences on Land-Atmosphere Fluxes, J. Climate, 25, 48394859, doi:10.1175/JCLI-D-11-00446.1, 2012.

Lindeskog, M., Arneth, A., Bondeau, A., Waha, K., Seaquist, J., Olin, S., and Smith, B.: Implications of accounting for land use in simulations of ecosystem carbon cycling in Africa, Earth Syst. Dynam., 4, 385-407, doi:10.5194/esd-4-385-2013, 2013.

Liu, J. G., Williams, J. R., Zehnder, A. J. B., and Yang, H.: GEPIC - modelling wheat yield and crop water productivity with high resolution on a global scale, Agr. Syst., 94, 478-493, doi:10.1016/j.agsy.2006.11.019, 2007.

Mueller, N. D., Gerber, J. S., Johnston, M., Ray, D. K., Ramankutty, N., and Foley, J. A.: Closing yield gaps through 
nutrient and water management, Nature, 490, 254-257, doi:10.1038/nature11420, 2012.

Müller, C. and Robertson, R.: Projecting future crop productivity for global economic modeling, Agric. Econom., 45, 37-50, doi:10.1111/agec.12088, 2014.

Nelson, G. C., Valin, H., Sands, R. D., Havlík, P., Ahammad, H., Deryng, D., Elliott, J., Fujimori, S., Hasegawa, T., Heyhoe, E., Kyle, P., Von Lampe, M., Lotze-Campen, H., Mason d'Croz, D., van Meijl, H., van der Mensbrugghe, D., Müller, C., Popp, A., Robertson, R., Robinson, S., Schmid, E., Schmitz, C., Tabeau, A., and Willenbockel, D.: Climate change effects on agriculture: Economic responses to biophysical shocks, P. Natl. Acad. Sci., 111, 3274-3279, 10.1073/pnas.1222465110, 2014.

Okada, M., Iizumi, T., Hayashi, Y., and Yokozawa, M.: Modeling the multiple effects of temperature and radiation on rice quality, Environ. Res. Lett., 6, 034031, doi:10.1088/17489326/6/3/034031, 2011.

Peel, M. C., Finlayson, B. L., and McMahon, T. A.: Updated world map of the Köppen-Geiger climate classification, Hydrol. Earth Syst. Sci., 11, 1633-1644, doi:10.5194/hess-11-16332007, 2007.

Piontek, F., Müller, C., Pugh, T. A. M., Clark, D. B., Deryng, D., Elliott, J., Colón González, F. d. J., Flörke, M., Folberth, C., Franssen, W., Frieler, K., Friend, A. D., Gosling, S. N., Hemming, D., Khabarov, N., Kim, H., Lomas, M. R., Masaki, Y., Mengel, M., Morse, A., Neumann, K., Nishina, K., Ostberg, S., Pavlick, R., Ruane, A. C., Schewe, J., Schmid, E., Stacke, T., Tang, Q., Tessler, Z. D., Tompkins, A. M., Warszawski, L., Wisser, D., and Schellnhuber, H. J.: Multisectoral climate impact hotspots in a warming world, P. Natl. Acad. Sci., 111, 32333238, doi:10.1073/pnas.1222471110, 2014.

Portmann, F. T., Siebert, S., Bauer, C., and Döll, P.: Global data set of monthly growing areas of 26 irrigated crops, Institute of Physical Geography, University of Frankfurt, Frankfurt am Main, GermanyFrankfurt Hydrology Paper 06, 400, 2008.

Portmann, F. T., Siebert, S., and Döll, P.: MIRCA2000-Global monthly irrigated and rainfed crop areas around the year 2000: A new high-resolution data set for agricultural and hydrological modeling, Global Biogeochem. Cy., 24, Gb1011, doi:10.1029/2008gb003435, 2010.

Potter, P., Ramankutty, N., Bennett, E. M., and Donner, S. D.: Characterizing the Spatial Patterns of Global Fertilizer Application and Manure Production, Earth Interactions, 14, 1-22, doi:10.1175/2009EI288.1, 2010.

Ray, D. K., Ramankutty, N., Mueller, N. D., West, P. C., and Foley, J. A.: Recent patterns of crop yield growth and stagnation, Nat. Commun., 3, 1293, doi:10.1038/ncomms2296, 2012.

Ray, D. K., Mueller, N. D., West, P. C., and Foley, J. A.: Yield Trends Are Insufficient to Double Global Crop Production by 2050, Plos One, 8, e66428, doi:10.1371/journal.pone.0066428, 2013.

Rosen, C. J. and Bierman, P. M.: Using manure and compost as nutrient sources for fruit and vegetable crops, Publication of the Department of Soil, Water, and Climate University of Minnesota, 2005.

Rosenzweig, C., Jones, J. W., Hatfield, J. L., Ruane, A. C., Boote, K. J., Thorburne, P., Antle, J. M., Nelson, G. C., Porter, C., Janssen, S., Asseng, S., Basso, B., Ewert, F., Wallach, D., Baigorria, G., and Winter, J. M.: The Agricultural
Model Intercomparison and Improvement Project (AgMIP): Protocols and pilot studies, Agr. Forest Meteorol., 170, 166-182, doi:10.1016/j.agrformet.2012.09.011, 2013.

Rosenzweig, C., Elliott, J., Deryng, D., Ruane, A. C., Müller, C., Arneth, A., Boote, K. J., Folberth, C., Glotter, M., Khabarov, N., Neumann, K., Piontek, F., Pugh, T. A. M., Schmid, E., Stehfest, E., Yang, H., and Jones, J. W.: Assessing agricultural risks of climate change in the 21 st century in a global gridded crop model intercomparison, P. Natl. Acad. Sci., 111, 3268-3273, doi:10.1073/pnas.1222463110, 2014.

Ruane, A. C., McDermid, S., Rosenzweig, C., Baigorria, G. A., Jones, J. W., Romero, C. C., and DeWayne Cecil, L.: CarbonTemperature-Water change analysis for peanut production under climate change: a prototype for the AgMIP Coordinated ClimateCrop Modeling Project (C3MP), Glob. Change Biol., 20, 394407, doi:10.1111/gcb.12412, 2014.

Ruane, A. C., Goldberg, R., and Chryssanthacopoulos, J.: Climate forcing datasets for agricultural modeling: Merged products for gap-filling and historical climate series estimation, Agr. Forest Meteorol., 200, 233-248, doi:10.1016/j.agrformet.2014.09.016, 2015.

Sacks, W. J., Deryng, D., Foley, J. A., and Ramankutty, N.: Crop planting dates: an analysis of global patterns, Global Ecol. Biogeogr., 19, 607-620, doi:10.1111/j.1466-8238.2010.00551.x, 2010.

Saha, S., Moorthi, S., Pan, H.-L., Wu, X., Wang, J., Nadiga, S., Tripp, P., Kistler, R., Woollen, J., Behringer, D., Liu, H., Stokes, D., Grumbine, R., Gayno, G., Wang, J., Hou, Y.-T., Chuang, H.Y., Juang, H.-M. H., Sela, J., Iredell, M., Treadon, R., Kleist, D., Van Delst, P., Keyser, D., Derber, J., Ek, M., Meng, J., Wei, H., Yang, R., Lord, S., Van Den Dool, H., Kumar, A., Wang, W., Long, C., Chelliah, M., Xue, Y., Huang, B., Schemm, J.-K., Ebisuzaki, W., Lin, R., Xie, P., Chen, M., Zhou, S., Higgins, W., Zou, C.-Z., Liu, Q., Chen, Y., Han, Y., Cucurull, L., Reynolds, R. W., Rutledge, G., and Goldberg, M.: The NCEP Climate Forecast System Reanalysis, B. Am. Meteorol. Soc., 91, 1015-1057, doi:10.1175/2010BAMS3001.1, 2010.

Sheffield, J., Goteti, G., and Wood, E. F.: Development of a 50Year High-Resolution Global Dataset of Meteorological Forcings for Land Surface Modeling, J. Climate, 19, 3088-3111, doi:10.1175/JCLI3790.1, 2006.

Smith, B., Prentice, I. C., and Sykes, M. T.: Representation of vegetation dynamics in the modelling of terrestrial ecosystems: comparing two contrasting approaches within European climate space, Global Ecol. Biogeogr., 10, 621-637, 2001.

Song, Y., Jain, A. K., and McIsaac, G. F.: Implementation of dynamic crop growth processes into a land surface model: evaluation of energy, water and carbon fluxes under corn and soybean rotation, Biogeosciences, 10, 8039-8066, doi:10.5194/bg10-8039-2013, 2013.

Stehfest, E., Heistermann, M., Priess, J. A., Ojima, D. S., and Alcamo, J.: Simulation of global crop production with the ecosystem model DayCent, Ecol. Model., 209, 203-219, doi:10.1016/j.ecolmodel.2007.06.028, 2007.

Stöckle, C. O., Donatelli, M., and Nelson, R.: CropSyst, a cropping systems simulation model, Eur. J. Agron., 18, 289-307, doi:10.1016/S1161-0301(02)00109-0, 2003.

Supit, I., Hooijer, A. A., and van Diepen, C. A.: System description of the WOFOST 6.0 crop simulation model implemented in 
CGMS, EUR; 15956 EN, Office for Official Publications of the European Commission, Luxembourg, 1994.

Tao, F. and Zhang, Z.: Climate Change, High-Temperature Stress, Rice Productivity, and Water Use in Eastern China: A New Superensemble-Based Probabilistic Projection, J. Appl. Meteorol. Climatol., 52, 531-551, 10.1175/JAMC-D-12-0100.1, 2012.

Taylor, K. E., Stouffer, R. J., and Meehl, G. A.: An Overview of CMIP5 and the Experiment Design, Bull. Am. Meteorol. Soc., 93, 485-498, doi:10.1175/BAMS-D-11-00094.1, 2012.

Thoning, K. W., Tans, P. P., and Komhyr, W. D.: Atmospheric carbon dioxide at Mauna Loa Observatory: 2. Analysis of the NOAA GMCC data, 1974-1985, J. Geophys. Res.-Atmos., 94, 8549-8565, doi:10.1029/JD094iD06p08549, 1989.

Valade, A., Ciais, P., Vuichard, N., Viovy, N., Caubel, A., Huth, N., Marin, F., and Martiné, J.-F.: Modeling sugarcane yield with a process-based model from site to continental scale: uncertainties arising from model structure and parameter values, Geosci. Model Dev., 7, 1225-1245, doi:10.5194/gmd-7-12252014, 2014.

Van den Hoof, C., Hanert, E., and Vidale, P. L.: Simulating dynamic crop growth with an adapted land surface model - JULESSUCROS: Model development and validation, Agr. Forest Meteorol., 151, 137-153, doi:10.1016/j.agrformet.2010.09.011, 2011. van Diepen, C. A., Wolf, J., van Keulen, H., and Rappoldt, C.: WOFOST: a simulation model of crop production, Soil Use Manage., 5, 16-24, doi:10.1111/j.1475-2743.1989.tb00755.x, 1989.
Waha, K., van Bussel, L. G. J., Müller, C., and Bondeau, A.: Climate-driven simulation of global crop sowing dates, Global Ecol. Biogeogr., 21, 247-259, doi:10.1111/j.14668238.2011.00678.x, 2012.

Warszawski, L., Frieler, K., Huber, V., Piontek, F., Serdeczny, O., and Schewe, J.: The Inter-Sectoral Impact Model Intercomparison Project (ISI-MIP): Project framework, P. Natl. Acad. Sci. USA, 111, 3228-3232, doi:10.1073/pnas.1312330110, 2014.

Weedon, G. P., Gomes, S., Viterbo, P., Shuttleworth, W. J., Blyth, E., Österle, H., Adam, J. C., Bellouin, N., Boucher, O., and Best, M.: Creation of the WATCH Forcing Data and Its Use to Assess Global and Regional Reference Crop Evaporation over Land during the Twentieth Century, J. Hydrometeorol., 12, 823-848, doi:10.1175/2011JHM1369.1, 2011.

Weedon, G. P., Balsamo, G., Bellouin, N., Gomes, S., Best, M. J., and Viterbo, P.: The WFDEI meteorological forcing data set: WATCH Forcing Data methodology applied to ERAInterim reanalysis data, Water Resour. Res., 50, 7505-7514, doi:10.1002/2014WR015638, 2014.

Weyant, J. P., de la Chesnaye, F. C., and Blanford, G. J.: Overview of EMF-21: multigas mitigation and climate policy, Energy J., 27, 1-32, 2006. 